\title{
Exogenous application of vitamins in upland rice
}

\section{Eduardo Pradi Vendruscolo', Aliny Heloísa Alcântara Rodrigues ${ }^{2}$, Paulo Ricardo Oliveira ${ }^{2}$, Rodrigo Andrade Leitão ${ }^{2}$, Luiz Fernandes Cardoso Campos ${ }^{3}$, Alexander Seleguini ${ }^{4}$, Sebastião Ferreira de Lima $^{5}$}

\author{
${ }^{1}$ Universidade Estadual do Mato Grosso do Sul, Unidade Universitária de Cassilândia, Cassilândia, Mato Grosso do Sul, Brasil. E- \\ mail: agrovendruscolo@gmail.com \\ ${ }^{2}$ Universidade Federal de Goiás, Escola de Agronomia, Goiânia, Goiás, Brasil. E-mail: aliny_heloisa@ hotmail.com, \\ paulokktto@gmail.com,r.d.07@hotmail.com \\ ${ }^{3}$ Universidade Estadual de Goiás, Campus de São Luís de Montes Belos, São Luís de Montes Belos, Goiás, Brasil. E-mail: \\ luizfernandescampos@hotmail.com \\ ${ }^{4}$ Universidade Federal do Triângulo Mineiro, Campus Universitário de Iturama, Iturama, Minas Gerais, Brasil. E-mail: \\ aseleguini@gmail.com
}

${ }^{5}$ Universidade Federal de Mato Grosso do Sul, Campus de Chapadão do Sul, Chapadão do Sul, Mato Grosso do Sul, Brasil. E-mail: sebastiao.lima@ufms.br

Received: 14/12/2018; Accepted: 28/01/2019.

\section{ABSTRACT}

Vitamin application can optimize plant growth and grain yield of rice crop due to its beneficial effect on many plant physiological characteristics. The present study was conducted to evaluate the effects of niacin and thiamin applied as seed soaking or foliar spray on the morphological and productive characteristics of upland rice crop (Oryza sativa L., cv. Primavera), grown under greenhouse conditions. The experiment was arranged in a randomized block design in a $4 \times 2$ factorial scheme, with four replicates. The treatments consisted of the application of vitamins (control; $200 \mathrm{mg} \mathrm{L}^{-1}$ thiamin; $200 \mathrm{mg} \mathrm{L}^{-1}$ niacin; and $100 \mathrm{mg} \mathrm{L}^{-1}$ thiamin $+100 \mathrm{mg} \mathrm{L}^{-1}$ niacin) and two application methods (seed soaking and foliar spraying). Morphological and productive characteristics of the rice plants were evaluated. The exogenous application of thiamin and niacin, regardless of the application method, has a beneficial effect on the growth of upland rice plants, but does not increase the grain yield of the crop.

Keywords: Oryza sativa L., Vitamin B3, Vitamin B1, Biostimulant action, Plant protection.

\section{Aplicação exógena de vitaminas em arroz de terras altas}

\section{RESUMO}

A aplicação de vitaminas pode otimizar o crescimento e o rendimento de grãos da cultura do arroz devido ao seu efeito benéfico em muitas características fisiológicas das plantas. O objetivo desse trabalho foi avaliar os efeitos da aplicação de niacina e tiamina, via tratamento de sementes e via aplicação foliar, nas características de desenvolvimento vegetativo e produtivo do arroz de terras altas (cv. Primavera), cultivado em condições de ambiente de cultivo protegido. $\mathrm{O}$ experimento foi delineado em blocos casualizados em esquema fatorial $4 \times 2$, com 4 repetições. Os tratamentos constituíram da aplicação de vitaminas (controle; $200 \mathrm{mg} \mathrm{L}^{-1}$ de tiamina; $200 \mathrm{mg}$ $\mathrm{L}^{-1}$ de niacina; e $100 \mathrm{mg} \mathrm{L}^{-1}$ de tiamina $+100 \mathrm{mg} \mathrm{L}^{-1}$ de niacina) e de duas formas de aplicação (via semente e via foliar). Foram avaliadas as características morfológicas e produtivas das plantas de arroz. A aplicação exógena de tiamina e niacina, independentemente do método de aplicação, possui efeito positivo no desenvolvimento vegetativo das plantas de arroz de terras altas, não alterando, no entanto, o rendimento de grãos da cultura.

Palavras-chave: Oryza sativa L., Vitamina B3, Vitamina B1, Ação bioestimulante, Proteção vegetal. 


\section{Introduction}

Rice (Oryza sativa L.) is one of the most important cereal crops for food in the world. With around 740 million tons of grain produced annually in more than 120 countries worldwide, rice is the third crop with the highest grain production in the world, surpassed only by maize and wheat (FAO, 2018). In this context, Brazil is the ninth largest producer in the world, producing 11.5 million tons in an area of 1.9 million hectares (FAO, 2018).

Most of the Brazilian rice is grown in irrigated systems, with high grain yield, while $10 \%$ of the grains are produced in the non-irrigated system or drylands (Oliveira Neto, 2015). Despite the importance of upland rice cultivation in the regions of agricultural expansion and rotation with other crops, its yield is still low when compared to rice grown in lowland areas. In this way, the use of technologies that help to increase grain yield has great value, in order to make upland rice cultivation attractive to the producer. In this sense, the use of biostimulant action elements has been investigated. Among the many products marketed, new elements with potential use in agricultural production, such as vitamins, are sought.

The B vitamins, such as thiamin and niacin, have been used as biostimulating action elements to alleviate stresses from the growing environment (Ahn et al., 2005; Boubakri et al., 2012; Kaya et al., 2015; Abdallah et al., 2016).

The exogenous application of these elements can lead to gains in the morphological and physiological characteristics of the plants, reflected in the increase of energy and nutritional reserves (Barakat, 2003; ElBassiouny, 2005), improving plant growth and development (Taiz et al., 2017).

Among the studies carried out with the application of these vitamins, there were reported increases in the morphological and productive characteristics of the wheat crop, when the seeds were submitted to the application of $5 \mathrm{mg} \mathrm{L}^{-1}$ thiamin solution (El-Bassiouny et al., 2014).

The thiamin application as seed soaking or foliar spraying increased the $\mathrm{N}, \mathrm{P}, \mathrm{Ca}$ and $\mathrm{K}$ concentrations in the foliar tissues of maize grown under salt stress conditions (Kaya et al., 2015). The beneficial effect of vitamin application was also reported for the crops of quinoa (Abdallah et al., 2016), marigold (Soltani et al., 2014), mustard (Azhar and Khan, 2015; Vendruscolo et al., 2017) and common beans (Vendruscolo et al., 2018). However, the effect of applying these vitamins on the growth and grain yield of the upland rice crop is still unknown.

Thus, this study aimed to evaluate the effects of the niacin and thiamin applied as seed soaking or foliar spraying on the morphological and productive characteristics of rice upland (cv. Primavera), grown under greenhouse conditions.

\section{Material and Methods}

The study was conducted in an experimental area belonging to the Agronomy School of the Goiás Federal University, in Goiânia, Goiás, Brazil (16² 40' S, 49 15' $\mathrm{W}$, and $750 \mathrm{~m}$ altitude).

The regional climate, according to the KÖPPENGEIGER classification, is Aw, characterized as the tropical climate with a rainy season from October to April and a period with rainfall rates below $100 \mathrm{~mm}$ between May and September. The mean monthly temperatures range from $20.8{ }^{\circ} \mathrm{C}$ in June and July to $25.3{ }^{\circ} \mathrm{C}$ in October (Cardoso et al., 2014).

Samples of a sandy clay loam soil classified as LATOSSOLO VERMELHO distroférrico (Santos et al., 2013) were collected in the $0-0.20 \mathrm{~m}$ depth and used in this study. The soil had the following chemical characteristics: $\mathrm{Ca}^{2+}: 3.2 \mathrm{cmol}_{\mathrm{c}} \mathrm{dm}^{-3}, \mathrm{Mg}^{2+}: 1.5 \mathrm{cmol}_{\mathrm{c}}$ $\mathrm{dm}^{-3}, \mathrm{~K}^{+}: 52.0 \mathrm{mg} \mathrm{dm}^{-3}$, P (Mehlich-1): $28.0 \mathrm{mg} \mathrm{dm}^{-3}$, organic matter: $1.6 \%, \mathrm{Al}^{3+}: 0,0 \mathrm{cmol}_{\mathrm{c}} \mathrm{dm}^{-3}, \mathrm{H}+\mathrm{Al}: 1.5$ $\mathrm{cmol}_{\mathrm{c}} \mathrm{dm}^{-3}$ and $\mathrm{pH}$ inCaCl $\mathrm{C}_{2}$ : 5.6, cation exchange capacity: $6.33 \mathrm{cmol}_{\mathrm{c}} \mathrm{dm}^{-3}$, soil base saturation: $77.0 \%$. All soil chemical analyses were performed according to the methodology proposed by Embrapa (2011). According to the Embrapa (2009) methodology, soil particle size analysis presented $270 \mathrm{~g} \mathrm{~kg}^{-1}$ of clay, $200 \mathrm{~g}$ $\mathrm{kg}^{-1}$ of silt and $530 \mathrm{~g} \mathrm{~kg}^{-1}$ of sand.

The experiment was conducted in a randomized complete block design in a $4 \times 2$ factorial scheme with four replicates. The treatments were defined by the application of vitamins (control; $200 \mathrm{mg} \mathrm{L}^{-1}$ thiamin; $200 \mathrm{mg} \mathrm{L}^{-1}$ of niacin; and $100 \mathrm{mg} \mathrm{L}^{-1}$ of thiamin +100 $\mathrm{mg} \mathrm{L}^{-1}$ of niacin) and two application methods (seed soaking or foliar spraying). Seed soaking was performed by immersing the seeds in the solutions for $24 \mathrm{~h}$. After this period, the seeds were removed from the solutions, placed to dry in the shade on sheets of paper towel, for 30 minutes, and they were sown. A manual sprayer containing the solutions of each treatment was used for foliar spraying. Mineral oil was used as an adjuvant at a rate of $756 \mathrm{~g} \mathrm{~L}^{-1}$. The plants were sprayed in the posttillering stage so that the solution was covering all leaves.

In pots with $18 \mathrm{dm}^{3}$ capacity, ten upland rice seeds (cv. Primavera) were sown on September 20, 2017. Seeds were arranged in a line in the central part of the pot, at a depth of $3 \mathrm{~cm}$, with only two plants being maintained after the beginning of tillering. Irrigation was performed daily by the drip system. During the experiment, the control of bedbugs (Tibraca limbativentris) was proceeded by applying insecticide based on Lambda-cyhalothrin $\left(50 \mathrm{~g} \mathrm{~L}^{-1}\right.$ of i.a.) at 30 
days after sowing. The application of limestone and fertilizers were not performed in this study.

At 90 days after sowing, the relative levels of chlorophylls "a", "b" and total were quantified using the digital chlorophyll meter $\left(\right.$ Falker $\left.^{\circledR}\right)$. The other evaluations were performed at 113 days after sowing when the crop was at physiological maturity phase. The plant height, number of tillers, panicle number and leaf number were measured.

The grains were harvested in order to determine the mass of 100 grains and grain production per plant. The fertility of the panicles was estimated using the ratio of fertile spikelets to the total number of spikelets in the panicle.

The plants were cut close to the soil surface and weighed to obtain the shoot fresh mass, whereas the shoot dry mass was obtained after drying in a forced air circulation oven $\left(65^{\circ} \mathrm{C}\right)$, until obtaining a constant mass.

The data were submitted to analysis of variance, and when significant the means were compared by the Tukey test $(\mathrm{P}<0.05)$.
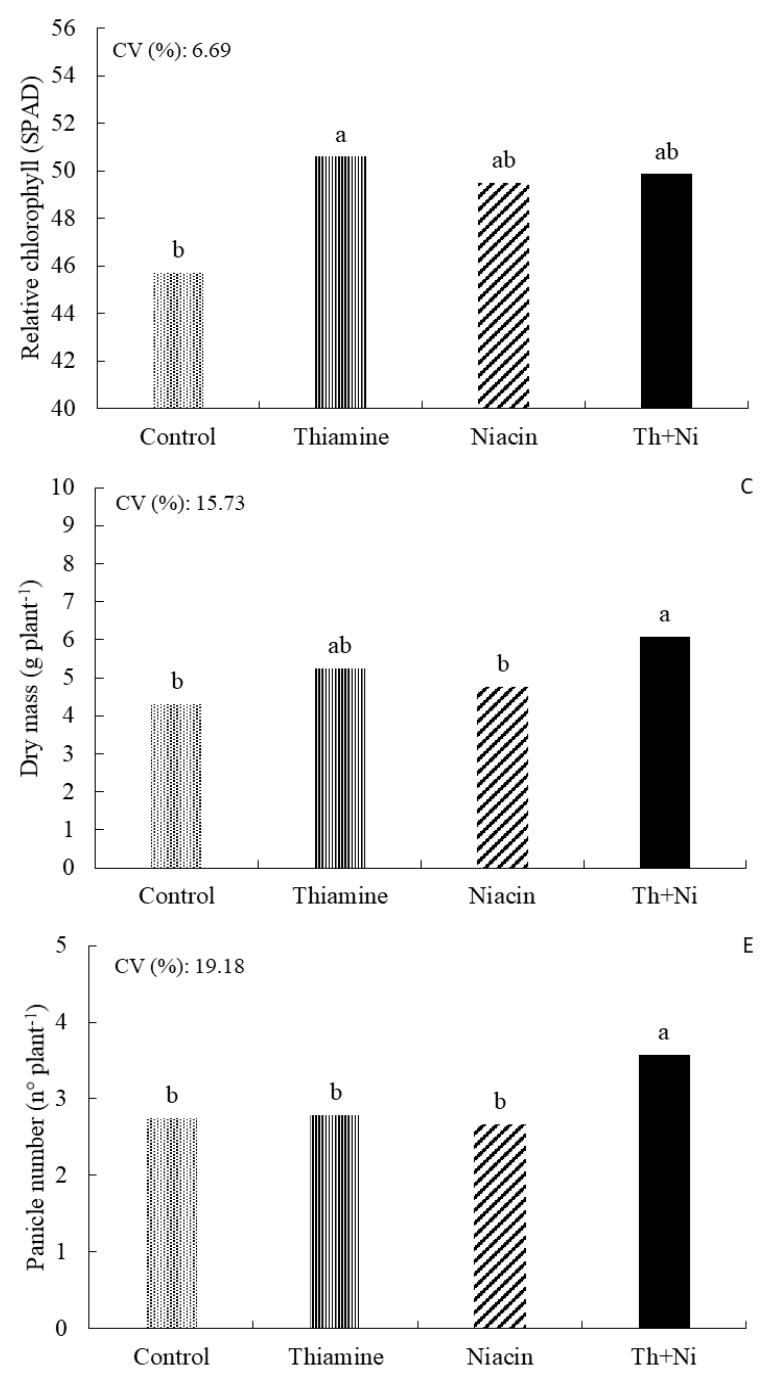

\section{Results and Discussion}

Exogenous application of vitamins either as seed soaking or as foliar spraying provided increases in most of the morphophysiological characteristics of rice plants (Figure 1), except for plant height and leaf number per plant. For these characteristics were observed the average height of $64.40 \mathrm{~cm}$ and plants with 10.90 leaves. The plant height value was below those described by Soares et al. (2001) for the cv. Primavera, which reported an average height of $101 \mathrm{~cm}$. Also, there was no interaction between vitamins and application methods for these characteristics.

The application of thiamin alone increased the relative chlorophyll index compared to control plants, but did not differ statistically from the application of niacin alone and combined application of the two vitamins (Figure 1A). About the control plants, without the application of vitamins, there were increases of $10.68 \%, 8.31 \%$ and $9.08 \%$ in the relative chlorophyll index, respectively, in the treatments with the isolated application of thiamin and niacin and with the combined application of two vitamins.
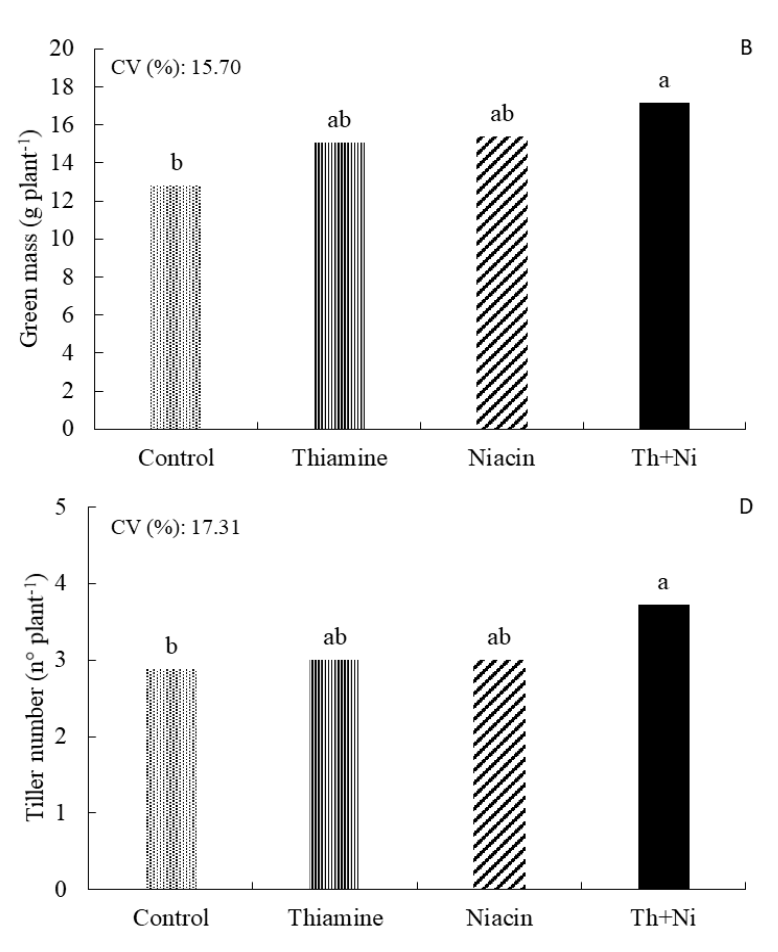

(1)

Figure 1. Relative chlorophyll index (A), shoot fresh matter (B), shoot dry matter (C), tiller number (D) and panicle number (E) of upland rice plants (Oryza sativa L., cv. Primavera) submitted to the exogenous application of vitamins (thiamin and/or niacin). 
Thiamin acts as a promoter of the secondary metabolites production, with antioxidant action, protecting the photosystem components (Kaya et al., 2015). This vitamin also acts as a carbon metabolism regulator in protein synthesis (Kaya et al., 2015) and participates as a coenzyme in a series of metabolic processes, which are essential to the proper growth and development of plants (Goyer, 2010; Taiz et al., 2017).

The highest accumulation of shoot fresh matter mass was observed with the combined application of the two vitamins, but did not differ significantly from the treatments with the isolated application of the vitamins (Figure 1B). The treatments with thiamin or niacin provided an increase of $17.30 \%$ and $20.03 \%$, while the combined application increased by $33.83 \%$ of the shoot fresh matter. For the shoot dry matter, it was also observed that the combined application resulted in greater mass accumulation (Figure 1C), not differing only from the treatment with thiamin application and surpassing the control treatment in $1.77 \mathrm{~g}$ (i.e., $41.16 \%$ ).

Similar results were reported by Soltani et al. (2014), Hendawy and Ezz El-Din (2010), Abdallah et al. (2016) and Vendruscolo et al. (2017), which works with marigold, oregano, quinoa, and curly mustard, respectively, observed an increase in the vegetative and reproductive development of the plants when they were submitted to different treatments with vitamins. These responses can be attributed to the increase in energy and nutritional reserves of the plants, improving the development and production of the crops (El-Bassiouny et al., 2014).

The combined application of the two vitamins increased the number of tillers (Figure 1D) and panicles (Figure 1E) per plant, regardless of the application method. However, for the number of tillers, there was no significant difference for the treatments with the isolated application of the vitamins. The combined application of thiamin and niacin resulted in an increase of $29.17 \%, 24.00 \%$ and $24.00 \%$ in tiller number and $30.18 \%, 28.32 \%$ and $34.08 \%$ in panicle number compared to treatment without vitamin application, and with the isolated application of thiamin or niacin, respectively. The positive effects of the exogenous application of vitamins were also observed for wheat crop when the plants of two cultivars were grown under different fertilization management. In this study, ElBassiouny et al. (2014) reported that the exogenous application of the vitamin increased the morphological, metabolic, nutritional and productive characteristics of the plants, both with the recommended fertilization application and with half of the fertilization rate.

There was no significant difference in the grain yield between the treatments studied, and the average for this characteristic was $1.96 \mathrm{~g} \mathrm{plant}^{-1}$. This result remains below the values obtained for this cultivar under field conditions, with a spacing of $0.40 \mathrm{~m}$ between rows and density of 70 seeds $\mathrm{m}^{-1}$ (Soares et al., 2001), possibly due to the conditions of plant growth in the present study, in pots.

The fertility of the spikelets was affected by the factors studied (Figure 2). The immersion of the seeds only in water (control) resulted in spikelet fertility gains of $9.93 \%$, about the same treatment applied as spraying on the leaves, while foliar spraying increased the spikelet fertility by $5.30 \%$ from plants treated with the two vitamins in combination. Among the treatments with the vitamin solutions, a significant difference was verified only when the foliar spraying was carried out, where it was verified the increase of the fertility of the spikelets with the exogenous application of the vitamins. Regarding the control treatment, treatments containing thiamin and niacin alone or two vitamins in combination increased the characteristic by $12.15 \%$, $9.20 \%$, and $13.33 \%$, respectively.

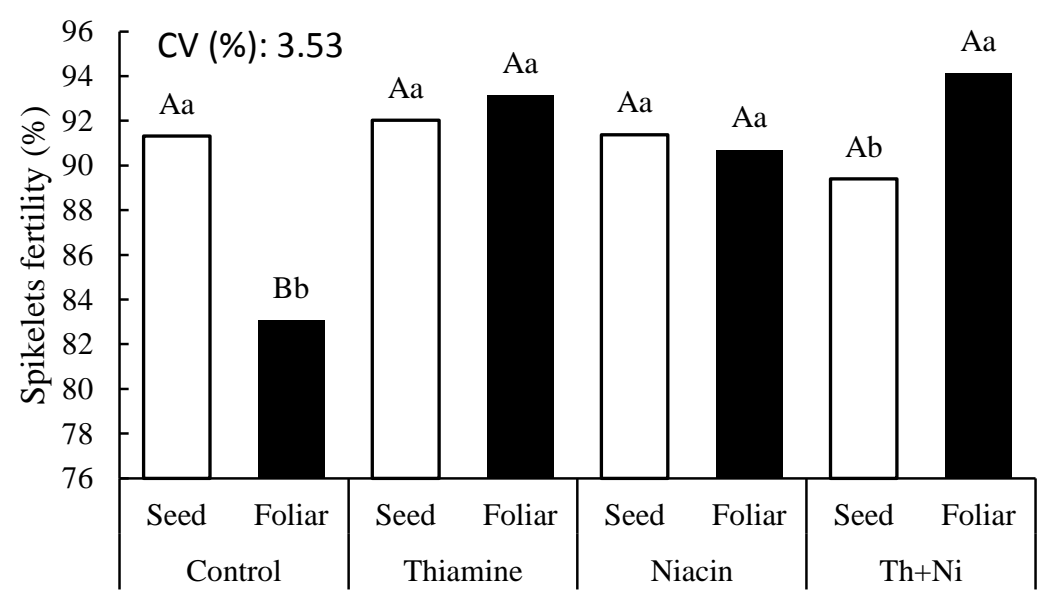

Figure 2. Spikelets fertility of upland rice plants (Oryza sativa L., cv. Primavera) submitted to exogenous application of niacin and thiamin as seed soaking or foliar spraying. Different letters, lowercase, and uppercase mean the presence of a significant difference between them for the application methods and vitamins applied, respectively. 
The difference observed for the control treatment, between the seed soaking and foliar spraying, is due to the hydration process of the seeds. In this process, the seed passes through different stages, in which the nutrient reserves present in the endosperm are distributed and translocated, supplying the embryo's demands until the plant becomes autotrophic (Franco et al., 1997; Taiz et al., 2017). For upland rice, this immersion period culminates in the formation of normal seedlings with greater vigor and initial growth rate (Franzin et al., 2007).

The increase of the spikelet fertility with the foliar spraying of vitamins is related to the biostimulating action of vitamins, increasing the energy and mineral reserves in the plants (Barakat, 2003; El-Bassiouny et al., 2014), which are indispensable for the vegetative and reproductive development (Taiz et al., 2017). The protective action also helps in the secondary metabolites production with antioxidant character, which allow the continuity of the photosynthetic processes (Kaya et al., 2015; Hassanein et al., 2009).

\section{Conclusions}

The exogenous application of thiamin and niacin, regardless of the application method, has a positive effect on the growth of upland rice plants, but does not increase the grain yield of the crop when grown under greenhouse conditions.

\section{Bibliographic References}

Abdallah, M.M.S., El Habbasha, S.F., El Sebai, T., 2016. Comparison of yeast extract and Nicotinaminde foliar applications effect on quinoa plants grown under sandy soil condition. International Journal of PharmTech Research, 9, 24-32.

Ahn, I.P., Kim, S., Lee, Y.H., 2005. Vitamin B1 functions as an activator of plant disease resistance. Plant Physiology, 138, 1505-1515.

Azhar, S., Khan, S., 2015. Enhancement of growth and yield of mustard (Brassica Juncea L.) var. Varuna by thiamine hydrochloride (Vitamin-B1) application. Journal of Functional and Environmental Botany, 5, 24-30.

Barakat, H.O.D.A., 2003. Interactive effects of salinity and certain vitamins on gene expression and cell division. International Journal of Agriculture and Biology, 5, 219-225.

Boubakri, H., Wahab, M.A., Chong, J., Bertsch, C., Mliki, A., Soustre-Gacougnolle, I., 2012. Thiamine induced resistance to Plasmopara viticola in grapevine and elicited host-defense responses, including HR like-cell death. Plant Physiology and Biochemistry, 57, 120-133.

Cardoso, M.R.D., Marcuzzo, F.F.N., Barros, J.R., 2014. Classificação climática de Köppen-Geiger para o estado de Goiás e o Distrito Federal. Acta Geográfica, 8, 40-55.
El-Bassiouny, H.M.S., 2005. Physiological responses of wheat to salinity alleviation by nicotinamide and tryptophan. International Journal of Agriculture and Biology, 7, 653-659.

El-Bassiouny, H.S.M., Bakry, B.A., Attia, A.A.E.M., Allah, M.M.A., 2014. Physiological role of humic acid and nicotinamide on improving plant growth, yield, and mineral nutrient of wheat (Triticum durum) grown under newly reclaimed sandy soil. Agricultural Sciences, 5, 687-700.

Embrapa - Empresa Brasileira de Pesquisa Agropecuária, 2009. Manual de análises químicas de solos, plantas e fertilizantes, segunda ed. Embrapa Informação Tecnológica, Brasília.

Embrapa - Empresa Brasileira de Pesquisa Agropecuária, 2011. Manual de métodos de análises de solos, segunda ed. Embrapa Solos, Rio de Janeiro.

FAOSTAT, 2018.2 Crops. http://www.fao.org/faostat/en/\#data/QC (Accessed March 18, 2019).

Franco, F., Petrini, J.A., Rodo, A., Livira A., Tavares W., 1997. Métodos para superação da dormência em sementes de arroz. Lavoura Arrozeira, 50, 11-15.

Franzin, S.M., Menezes, N.L., Garcia, D.C., Tillmann, M.A.A., 2007. Pré-germinação de sementes de arroz de sequeiro. Revista Brasileira de Sementes, 29, 68-75.

Goyer, A., 2010. Thiamine in plants: aspects of its metabolism and functions. Phytochemistry, 71, 1615-1624.

Hassanein, R.A., Bassony, F.M., Barakat, D.M., Khalil, R.R., 2009. Physiological effects of nicotinamide and ascorbic acid on Zea mays plant grown under salinity stress. Changes in growth, some relevant metabolic activities and oxidative defense systems. Research Journal of Agricultural and Biological Sciences, 5, 72-81.

Hendawy, S.F., Ezz El-Din A.A., 2010. Growth and yield of Foeniculum vulgar var. Azoricum as influensed by some vitamins and amino acids. Ozean Journal Applied Science, 3, 113-123.

Kaya, C., Ashraf, M., Sonmez, O., Tuna, A.L., Polat, T., Aydemir, S., 2015. Exogenous application of thiamin promotes growth and antioxidative defense system at initial phases of development in salt-stressed plants of two maize cultivars differing in salinity tolerance. Acta physiologiae plantarum, 37, 1741.

Oliveira Neto, A.A., 2015. A cultura do arroz. http://www.conab.gov.br (Accessed May 23, 2017).

Santos, H.G., Jacomine, P.K.T., Anjos, L.H.C., Oliveira, V.Á., Lumbreras, J.F., Coelho, M.R., Almeida, J.A., Cunha, T.J.F., Oliveira, J.B., 2013. Sistema Brasileiro de Classificação de Solos, terceira ed. Embrapa, Brasília.

Soares, A.A., Oliveira Cornelio, V.M., Soares, P.C., Santos, P.G., Reis, M.S., 2001. Primavera: cultivar de arroz com grãos agulhinha para cultivo em terras altas. Revista Ceres, 48, 381388 .

Soltani, Y., Saffari, V.R., Maghsoudi Moud, A.A., 2014. Response of growth, flowering and some biochemical 
constituents of Calendula officinalis L. to foliar application of salicylic acid, ascorbic acid and thiamine. EthnoPharmaceutical Products, 1, 37-44.

Taiz, L., Zeiger, E., Moller, I.M., Murphy, A., 2017. Plant Physiology and Development, sixth ed. Sinauer Associates, Sunderland.

Vendruscolo, E.P., Oliveira, P.R., Seleguini, A., 2017. Aplicação de niacina ou tiamina promovem incremento no desenvolvimento de mostarda. Cultura Agronômica, 26, 433 442 .
Vendruscolo, E.P., Rodrigues, A.H.A., Martins, A.P.B., Campos, L.F.C., Seleguini, A., 2018. Tratamento de sementes com niacina ou tiamina promove o desenvolvimento e a produtividade do feijoeiro. Journal of Agroveterinary Sciences, 17, 83-90. 